\title{
Financial constraint and foreign direct investment of SMEs: evidence from Portugal
}

\author{
Isabel Maria Machado Correia Brioso Dias ${ }^{1}$ - University of Minho, Braga, Portugal \\ Diana Santos Fernandes ${ }^{2}$ - University of Minho, Braga, Portugal
}

This work aims to explore the financing constraints perceived by Portuguese small and medium-sized enterprises (SMEs) carrying out productive foreign direct investment (FDI). It relies on primary data, presenting an explorative empirical analysis. The results evidence a strong dependence on internal funds and give little support to market failures in financing FDI, as no remarkable differences were found in financing constraints between domestic and foreign investments, but this reluctance of Portuguese SMEs towards external financing does not match with a willingness to open the social capital to new shareholders. Portuguese entrepreneurs lack knowledge of alternative financing sources to relieve dependence on domestic funds to FDI. Banks and government could relevantly contribute in this field, we also recommend further financial literacy in Portguese SMEs. This work is limited by its sample and qualitative nature. Although there is abundant literature on the access to economic agents' financing, to this day this work is the first to focus on Portuguese SMEs analysing primary data, hence its originality. Reporting SMEs' reluctance towards external financing, it can enhance external financers to best capture such clients.

JEL Classification: F23, F34, G32, L20, M13, M21.

Keywords: SMEs, FDI, financial constraints, internationalization.

\section{Restricción financiera e inversión extranjera directa de las PYME: evidencia de Portugal}

Este trabajo intenta explorar las limitaciones de financiación percibidas por las pequeñas y medianas empresas (PYMES) portuguesas que realizan inversiones directas extranjeras (IED) productivas. Se basa en datos primarios y presenta un análisis empírico exploratorio. Los resultados demuestran una fuerte dependencia de los fondos internos y ligero énfasis en las deficiencias del mercado en la financiación de la IED, no reportando diferencias notables en las limitaciones de financiación entre las inversiones nacionales y extranjeras, pero esta renuencia de las PYMES portuguesas a la financiación externa no se corresponde con la voluntad de abrir el capital social a nuevos accionistas. Los empresarios portugueses no conocen alternativas para aliviar la dependencia de los fondos nacionales a la IED. Los bancos y el gobierno podrían contribuir en este campo, también recomendamos una mayor alfabetización financiera en las PYMES portuguesas. Este trabajo está limitado por su muestra y su naturaleza cualitativa. Aunque existe abundante literatura sobre el acceso a la financiación de los agentes económicos, hasta el día de hoy este trabajo es el primero que se centra en las PYMES portuguesas a través de datos primarios, de ahí su originalidad. Al informar sobre la reticencia de las PYMES a la financiación externa, puede mejorar la capacidad de los financiadores externos en captar esos clientes. Clasificación JEL: F23, F34, G32, L20, M13, M21.

Palabras clave: PYME, IED, restricciones financieras, internacionalización.

${ }^{1}$ Corresponding Author: Isabel M. Correia; Escola de Economia e Gestão - Campus de Gualtar 4710-057 Braga; icorreia@eeg.uminho.pt; +351253604532https://orcid.org/0000-0002-6735-3148

* No source of funding for research development 


\section{Introduction}

International expansion is often considered as the main driver to firms' growth, and establishing a subsidiary abroad is likely the costliest entry mode. Although there is a vast literature on the relationship between financial constraints and exports, there are very few firm-level studies on the limitations faced by firms (particularly SMEs) in financing FDI. A notable exception is the work of De Maeseneire and Claeys (2012), presenting an exploratory study based on qualitative data from Belgian SMEs carrying out productive FDI. The authors found evidence of imperfections in the capital market, resulting in perceived financial barriers for SMEs, specifically in financing FDI. Our paper largely replicates that work, focusing on the financial constraints perceived by Portuguese SMEs in FDI.

SMEs assume particular relevance in Portugal: in 2016, they nearly accounted for $99.9 \%$ of the total number of companies, employing $79 \%$ of the workforce and contributing to $59 \%$ of the added value of the Portuguese economy. Given the Portuguese market constraints (incipient growth and small size), the internationalisation becomes crucial for the growth and sustainability of a large number of businesses (Trigo, Calapez, and Santos, 2009; Simões, Castro, and Rodrigues, 2001). The financial constraints become, then, an even more relevant issue in credit rationing context, due to the recent economic and financial crisis in Portugal. Empirical evidence (Barradas, Lagoa, Leão, \& Mamede, 2013) reports that firms difficulties increased during this period, and that both the difficulty in obtaining bank lend and the high interests are the main factors limiting investments.

Our paper contributes to expand the still very limited literature on SME's FDI financing, therefore, we develop arguments for why such companies are expected to face financing constrains when carrying out FDI projects and test them through an explorative empirical analysis. Using primary data, we explore the SMEs perceptions on FDI financing constraints: Section 2 takes up theoretical considerations on SMEs financing constraints and on the arguments underlying the hypothesis that these obstacles are even more severe in case of FDI financing. Section 3 describes methods and sample, and Section 4 presents the results. Discussion and concluding remarks follow in Section 5.

\section{Theoretical framework}

\subsection{SMEs financing and capital market failures}

Despite recognizing a high heterogeneity among SMEs, literature attributes to these a specific structure and dynamics. In particular, it reports additional constraints in accessing equity and bank financing (Franco and Haase, 2010; North, Baldock, and Ekanem, 2010; Akbar, Bortoluzzi, and Tracogna, 2014).

Modigliani and Miller (1958)'s seminal work states that, if capital markets were perfect, a firm's investment behaviour would be irrelevant to its financing decisions, to the extent that funding would depend solely on the projects' viability. However, Stiglitz and Weiss (1981) point out that, due to market imperfections (information asymmetries and agency costs), capital does not always flow 
to firms with profitable investment opportunities. Given the banks' incapacity to distinguish "good" from "bad" investments, they ration credit rather than increase interest rates, in order to avoid adverse selection.

Empirically, a wide evidence supports the hypothesis of imperfections in capital markets (Ćorić, 2010). These may restrict firms' access to external financing and lower its investment and growth level (for a review on the impact of financial constraints in firms' growth, see Hossain, Ibrahim, and Uddin, 2016). When a company faces funding restrictions, its investment will depend substantially on internally generated resources (cash flows and retained earnings) (Mulier, Schoors, \& Merlevede, 2016). Specifically, SMEs can be prevented from making economically and financially viable investments due to restrictions in obtaining external financing, because potential providers cannot readily verify the quality of the project in question (adverse selection problem) or ensure the funds will not be side-tracked to alternative projects (moral hazard problem) (Berger \& Udell, 2002). Firm size seems to be closely linked to the information asymmetry between lenders and borrowers. Broad evidence has shown that liquidity constraints increase as firm size decreases (Ferrando and Griesshaber, 2011; Coluzzi, Ferrando, and Martinez-Carrascal, 2015). There are several reasons why capital suppliers are reluctant to lend to SMEs or may require higher returns from them (Scherr, Sugrue, and Ward, 1993; Bãdulescu, 2010). Among others, literature points out that SMEs may present more risks than larger firms, and may also be more difficult to monitor, due to informational opacity. Bãdulescu (2010) and Knight and Liesch (2016) add the internal resources scarcity (financial, managerial, capabilities and experience) as important antecedents, moderators and mediators in the internationalisation process, performance and long-term survival of SMEs. On the contrary, large firms have public accounting information, which increases transparency and reduces the informational asymmetry. Additionally, larger firms are better diversified and have a lower probability of facing financial distress, enabling them to take on more leverage (Rajan \& Zingales, 1995).

Collateral is often used as a means to deal with moral hazard and adverse selection (Berger, Espinosa-Vega, Frame, and Miller, 2011; Cerqueiro, Ongena, and Roszbach, 2016). By requiring assets as guarantee, the creditor increases the borrower's cost of defaulting, reducing moral hazard (Arráiz, Meléndez, \& Stucchi, 2014). Simultaneously, collateral prevents adverse selection, because one can expect that only low-risk borrowers would be willing to pledge collateral (Arráiz, Meléndez, \& Stucchi, 2014).

SMEs usually rely on trade credit and banks as major sources of debt (Walker, 1989). First, because they usually do not obtain long-term debt or equity in traditional financial markets. Second, because SMEs' owners are often reluctant to sell capital and transfer control (Giudici and Paleari, 2000; Cressy and Olofsson, 1997; Howorth, 2001; Oakey, 2007; Mason and Kwok, 2010). Third, SMEs also seem to be particularly constrained in accessing specific forms of financing (Beck et al., 2005). Facing credit rationing, retained earnings become a critical source for financing SMEs' investments. In short, Klonowski (2012) summarizes SMEs financing options as follows: if the firm is profitable, its own resources may be used to support its expansion; if it is not, it must betake to external funds (mainly from banks, venture capital, and the government). Nevertheless, market imperfections create a discrepancy between the cost of internal and external financing, mainly due to the information asymmetry between firms and potential external creditors, which is prevalent in small firms (Hubbard, 1988). In addition, external finance tends to be more expensive for smaller 
enterprises once lending fixed costs are not proportional to the loan size, making small loans more expensive than large ones (European Commission, 2003).

\subsection{SMEs financing constraints: evidence}

Most of the empirical works on SMEs financing constraints rely on balance sheet information. Few studies use primary data on SMEs perceptions (Beck, Demirgüç-Kunt, and Maksimovic, 2005; De Maeseneire and Claeys, 2012; Wang, 2016). A third strand of literature uses both data sources, matching financial firm-level data with self-reported financial constraints (Ferrando and Griesshaber, 2011; (Coluzzi et al., 2015; Artola and Genre, 2011).

Studies based on SMEs perceptions report mixed evidence. Beck, Demirgüç-Kunt, Laeven, and Maksimovic (2006) and Beck, Demirguc-Kunt, and Martinez Peria (2008) state that size, as well as other firm characteristics such as age and ownership structure, significantly impact financing obstacles. For the Eurozone, Artola and Genre (2011) found that the importance of accessing finance declines linearly with firm size and that small and young firms were the most constrained by the financial crunch during the recent economic crisis. In the same line, Wang (2016), based on data from the World Bank Enterprise Survey, presents evidence that access to finance is the most frequently quoted obstacle to firms growth, and that SMEs are more likely to perceive it. Kuntchev, Ramalho, Rodríguez-Meza, and Yang (2012) also report that the probability of being credit constrained decreases with firm size.

Differently, Haniff, Akma, and Lee (2017) conclude that Malaysian SMEs perceptions on financial constraints are largely unfounded and result mainly from informational gaps and, for the Euro-Area, the European Central Bank Report (ECB, 2018) evidences that access to financing is SMEs' least important concern. Despite being the main source of external financing (compared with marketbased instruments and other financing sources), almost one-half of the interviewed SMEs reported that bank loans were not a relevant source of finance. The main reason pointed was that they do not need this type of financing, as internal funds are sufficient. Interest rate is the second more often mentioned reason for not relying on bank loans.

Concerning the identification of SMEs' main financial constraints, Beck et al. (2005) state the collateral requirements, bureaucracy, and the need for special connections with banks, as well as the high interest rates. Daskalakis, Jarvis, and Schizas (2013) found that Greek small entrepreneurs perceive high interest rates as the most important obstacle to SMEs' financing, under-evaluating risk, collateral and information variables. Also, loan procedures are the second most relevant restriction to debt financing. High interest rates, delays in loan approval/disbursement, and collateral requirements were the main financing difficulties reported by Malaysian SMEs (Haniff, Akma, \& Lee, 2017). The high costs of borrowing and the lack of consultant support were the main barriers to external financing identified by Wang (2016) in developing countries. 


\subsection{SMEs and FDI: financing constraints}

The choice of the international mode of operation is a fundamental strategic decision, as it determines the type and intensity of the firm's control over their activities abroad (Huett, Baum, Schwens, \& Kabst, 2014). FDI has an attractive set of benefits to explore, but requires additional resources and capabilities. It entails substantial fixed costs, part of which are sunk. Financial constraints faced by SMEs are supposed to be higher when FDI is chosen as entry mode, since it requires a higher resources' commitment and involves higher risk exposure (Minetti and Zhu, 2011; Bakare and Akinbode, 2017). The foreign assets limited amount of collateral also increases the risk of losses to creditors, therefore difficulting SMEs' access to lending (Boot, Thakor, and Udell, 1991; Bakare and Akinbode, 2017).

However, there is scarce research on the financial frictions' impact on firms' decision of investing abroad. Among few exceptions, the work of Buch, Kesternich, Lipponer, and Schnitzer (2009) for Germany, based on self-reported financial constraints, states that financial (and productivity) restrictions have a significant impact on German firms internationalization decision. In a more recent work, Buch, Kesternich, Lipponer, and Schnitzer (2014) analysed the impact of financial (and productivity) factors over the choice of becoming multinational, under limited internal funds conditions. From a theoretical perspective, the authors state that when financing FDI, firms face additional contractual frictions, which make the impact of financial constraints stronger for FDI than for exporting. However, contradicting the predicted by conventional models, the authors found that, if financial resources matter, the constraints should be more relevant to large firms, as they are more likely to consider expanding abroad. Despite being more financially constrained, as they are less productive, SMEs do not intend to invest abroad, and therefore perceive themselves as being less harmed by those financial constraints. Empirical results using financial data to measure financial constraints broadly confirm these predictions.

Beyond size, financial constraints may also arise from firm-specific (governance, production and organisational structures), sector-specific (possibilities for collateralization), or country-specific characteristics (financial markets' structures). Some empirical evidence (Buch et al. 2009, 2014) suggests that firms in service industries are more affected than firms in manufacturing, once the higher difficulty to collateralize the investment in service industries increases the cost of external finance.

\section{Methods and Sample}

\subsection{Methods}

To analyze the SMEs perceptions, we used an adapted version of the questionnaire designed by De Maeseneire and Claeys (2012). About $80 \%$ of the questions we used were directly retrieved from the questionnaire used by these authors. Nevertheless, the empirical analysis by De Maeseneire and Claeys (2012) focused on both the demand side (SMEs) and the supply side (banks) in regards to the financial constraints for SMEs' FDI projects, while the present work only focuses on the perceptions of the demand side. 
All questions were closed-ended. The questionnaire's first part comprised questions aimed to characterise SMEs and their FDI projects. The following questions asked the respondents to specify their degree of agreement with a set of statements, or the degree of importance of a list of factors. We used a five-level Likert scale, ranging from 1 (totally disagree/nothing important) to 5 (strongly agree/extremely important). "Don't know" ("?”) answer was also allowed. Through these questions, we intended to investigate how Portuguese SMEs finance their FDI projects and to what extent they perceive that funding obstacles constrain their FDI. In particular, we seek to provide evidence on the perceived differences in the financial constraints severity when FDI is concerned, compared with domestic investment projects, and what are the main factors that SMEs perceive to motivate the existence of bank-lending constraints for FDI. A first version of the questionnaire was pre-tested by academics, a representative of a business association and two bank officials. Specifically, it was sought to ascertain if the questions were easy to understand and to eliminate issues that were not relevant in the Portuguese context.

To access the reliability and internal consistency of the designed multiple-question Likert scale survey, the respective Cronbach's alpha was calculated, presenting a scale reliability coefficient of 0.90 .

The target population were the Portuguese SMEs that carried out productive FDI. Foreign and government-owned (totally or partially) were excluded from the analysis. Firms belonging to company groups were also excluded, given the possibility of cross funding within the group.

AMADEUS database was used to identify the target SMEs. This survey was conducted in October 2016 and identified 103 companies. These SMEs were contacted via telephone or email to confirm whether they met the requirements and also to inquire their willingness to fill in the questionnaire. The questionnaire was sent, by mail, to 31 SMEs that expressed their willingness to collaborate. A cover letter containing the authors' identification and the purpose of the study, and a response envelope, accompanied the questionnaire. Only 12 SMEs returned the questionnaire filled in (totally or partially). Given the low number of responses, even after a reminder, the process was repeated in the following two years. SMEs that did not express willingness to collaborate were contacted again, by email. The questionnaire was resent, by mail, to 40 SMEs that showed willingness to collaborate or that did not respond. Only eight out of these SMEs completed the questionnaire. From these three "waves" (February and March 2017 and in the same period of 2018 and 2019), 20 questionnaires were collected.

\subsection{Description of sample}

Respondents are mostly mature firms (Table 1). As young firms are usually associated to higher financing constraints, their low share in this study may induce to lower perceptions of finance obstacles. 
Table 1. Firms distribution by age

\begin{tabular}{|c|c|c|}
\hline & $\begin{array}{c}\text { Population } \\
\mathbf{N = 1 0 3}\end{array}$ & $\begin{array}{c}\text { Respondents } \\
\mathbf{N = 2 0}\end{array}$ \\
\hline Young (1 -5 years) & $2.9 \%$ & $5.0 \%$ \\
\hline Adult (6-20 years) & $34.0 \%$ & $40.0 \%$ \\
\hline Mature (>20 years) & $63.1 \%$ & $55.0 \%$ \\
\hline
\end{tabular}

The assets tangibility and the economic situation of the industry in which the company operates may influence the financing ability (and cost). Literature suggests that firms in industries with lower assets tangibility may face greater complications in obtaining bank financing, and that creditors' risk perception may be influenced by the business economic conjuncture (Myers, 1984; Harris and Raviv, 1991; Barbosa and Moraes, 2004). Inter-sectoral differences were also found by Coluzzi et al. (2015), whose results suggest that firms in the construction sector perceive higher financing constraints. The firms included in our sample are active in various industries (Table 2), but manufacturing and services are the most represented. As several firms operate in more than one industry, we considered its main activity as the criteria for the distribution by industry.

Table 2. Distribution of firms by industries

\begin{tabular}{|l|c|c|}
\hline & Population & Respondents \\
\hline Agriculture, hunting and related service activities & $2.0 \%$ & $0.0 \%$ \\
\hline Manufacturing & $30.6 \%$ & $35.0 \%$ \\
\hline Construction & $11.2 \%$ & $20.0 \%$ \\
\hline Wholesale & $21.4 \%$ & $5.0 \%$ \\
\hline Services & $34.7 \%$ & $30.0 \%$ \\
\hline Missing & & $10.0 \%$ \\
\hline
\end{tabular}

Summarising, the typical respondent is a SME that operates in Manufacturing or in Services, and has been in the market, on average, for 27 years.

The countries of SMEs' investment (Figure 1) reflect the preference by geographic (Spain) and cultural (Brazil) proximity. The African market relevance is also evident (with 17 FDI projects in countries with Portuguese official language).

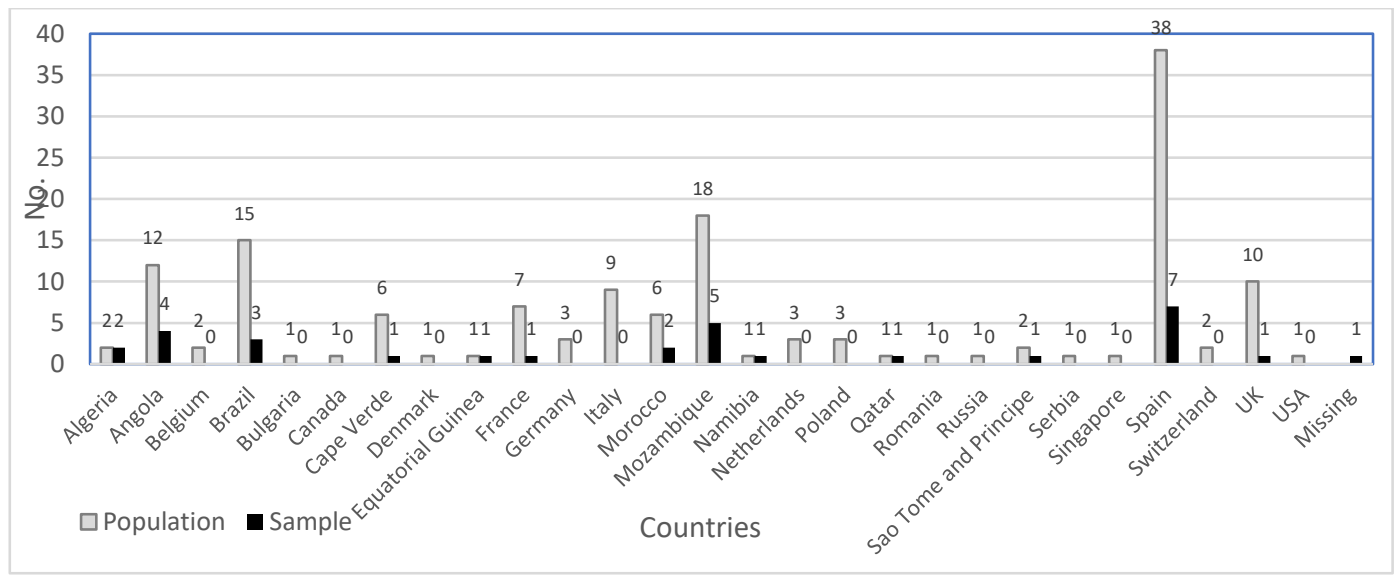

Figure 1. Host country of FDI (Number of Projects) 
The average amount of FDI is about 1 million Euros, ranging from $1900 €$ to $8000000 €$ (median $=307.5$ thousand Euros). Comparing the risk of the last FDI project with the risk of a similar domestic investment, using a Likert scale from 1 ("The risk is not higher") to 5 ("The risk is clearly higher"), score "4" was the most frequent response (mean: $3.87 \pm 0.74$ ), suggesting that foreign investments are perceived as more risky (compared to a similar project in Portugal).

\section{Results}

\subsection{SMEs financing on FDI projects}

This section analyses the main financing sources used by Portuguese SMEs (Table 3) and their perceptions on the barriers to its use (Tables 4 and 5). Our focus embraces local (host country) and domestic (home country) bank finance, as well as equity rising (internally and externally).

\subsubsection{Internal financing}

Self-financing is the most used source for Portuguese SMEs. Table 3 evidences the importance of internal funds to FDI and shows that this dependence on internal finance does not seem to vary remarkably between domestic and foreign investments.

More than $80 \%$ of the SMEs reported that, if insufficient internal funds were generated, it would be very hard to finance their FDI projects (mean score: $4.20 \pm 0.83$ ). Indeed, 59\% of SMEs exclusively used these funds to finance their most recent FDI projects. Despite the perceptions that internal funds are critical for the ability to invest abroad, a single firm raised equity to finance FDI, suggesting that raising equity is far from being the most preferred financing source for FDI.

Table 3. Sources of financing FDI projects. "To what extent do you agree with the following statements?" (1: totally disagree; 5 : totally agree)

\begin{tabular}{|c|c|c|c|c|c|c|c|}
\hline \multirow[t]{2}{*}{ Item } & \multicolumn{5}{|c|}{ Scores (\%) } & \multirow{2}{*}{$\begin{array}{c}\text { Mean } \\
\text { (sd) }\end{array}$} & \multirow[t]{2}{*}{ Signif. } \\
\hline & 1 & 2 & 3 & 4 & 5 & & \\
\hline $\begin{array}{l}\text { "If my SME would generate insufficient internal funds, it } \\
\text { would be very hard to finance the FDI projects." }\end{array}$ & 0.0 & 5.0 & 10.0 & 45.0 & 40.0 & $\begin{array}{c}4.20 \\
(0.83)\end{array}$ & 0.000 \\
\hline $\begin{array}{l}\text { "For financing FDI, my SME is more dependent on } \\
\text { internal funds than for domestic projects (with } \\
\text { comparable risk)." }\end{array}$ & 15.0 & 15.0 & 30.0 & 25.0 & 5.0 & $\begin{array}{c}3.10 \\
(1.30)\end{array}$ & 0.791 \\
\hline ners do not want to invest more capital." & 5.9 & 23.5 & 41.2 & 11.8 & 17.7 & $\begin{array}{c}3.12 \\
(1.17)\end{array}$ & 1.000 \\
\hline $\begin{array}{l}\text { "My SME does not want to open the capital to new } \\
\text { members." }\end{array}$ & 10. & 5.3 & 10.5 & 21.1 & 52.6 & $\begin{array}{c}4.00 \\
(1.37)\end{array}$ & 0.013 \\
\hline "My SME & 52.9 & 29.4 & 11.8 & 0.0 & 5.9 & $\begin{array}{c}1.76 \\
(1.09)\end{array}$ & 0.001 \\
\hline the final financing & 5. & 10.0 & 15.0 & 20.0 & 50.0 & $\begin{array}{c}4.00 \\
(1.26)\end{array}$ & 0.013 \\
\hline $\begin{array}{l}\text { "My SME relies heavily on banks to } \mathrm{f} \\
\text { projects." }\end{array}$ & 30 & 30.0 & 15.0 & 25.0 & 0.0 & $\begin{array}{c}2.35 \\
(1.18)\end{array}$ & 0.144 \\
\hline
\end{tabular}


"My SME relies heavily on banks to finance domestic investments." 15.0 \begin{tabular}{l|l|l|l|}
30.0 & 25.0 & 25.0 & 5.0
\end{tabular} 2.75 (1.16) 0.607

This table provides an overview of the internal financing of FDI projects by the SMEs surveyed $(\mathrm{N}=20) . \%$ score represents the percentage of respondents that have marked each score for the statement. "Mean" indicates the mean score of the statement, and "(sd)" is the standard deviation of scores. "Don't know" ("?") answers were excluded. Significance reports the p-value from the two-sided sign-test $\left(\mathrm{H}_{0}\right.$ : the difference between median of the variable and $3=0$ ).

Respondents seem to be reluctant to invest more capital in the company. Only $29.5 \%$ disagree that SMEs partners are not willing to invest more capital (scores 1 and 2). Score 3 was the most chosen, suggesting that respondents do not have a very clear position on this subject.

Alongside the provision of a balanced financial situation, the use of own financing by the surveyed SMEs may also be explained by another perspective. Indeed, data in Table 3 suggests a reluctance of SMEs to open up their social capital to new shareholders, suggesting that companies do not admit loss of control in the business' administration as the price to pay for FDI. This issue also arises in connection with the lack of tax incentives, in the private sphere, for entrepreneurs to take this step effectively. A statistically significant correlation was obtained $(\rho=0.020)$ between the reluctance of the surveyed SMEs in opening their social capital to new investors and their age (mature firms) and sector of activity ( $\rho=0.029$ for manufacturing; $\rho=0.040$ for services). On the other hand, a statistical correlation was obtained between the sector of activity of the surveyed SMEs and their difficulty in attracting new shareholders, especially for the SMEs in the construction industry $(\rho=0.012)$.

\subsubsection{External financing}

Less than one-half (47\%) of the surveyed SMEs used external financing to fund FDI. For these, domestic bank credit represented, on average, $79 \%$ of the external funding. More than one-half of these firms relied exclusively on banks to finance FDI. One single firm used government grants, and other sources (such as venture capital or partnerships) were not used at all.

Raising capital externally seems to be the last option to finance FDI. Although the surveyed SMEs do not claim to struggle in attracting new partners, it seems clear that they do not intend to use this source. As a general trend, SMEs seem reluctant to open their capital to new partners. One-half of the respondents completely agree that raising equity from new partners is the last financing option they would look for. These perceptions align with the Pecking Order hypothesis (Myers, 1984).

Despite being the main source of external financing, our respondents do not claim to be heavily dependent on banks for neither domestic nor foreign investments. $60 \%$ of SMEs deny relying heavily on banks to finance FDI (mean: $2.35 \pm 1.18$ ). The mean score to the statement concerning domestic investments is slightly higher than for FDI. Nevertheless, the difference in medians is not statistically significant (sign-test $p$ value $=0.508$ ), suggesting no differences in the perceptions about dependence on banks taking into account the place of investment. A single firm used local bank financing. 


\subsection{Financing constraints to FDI}

\subsubsection{Local (foreign) bank financing}

The remarkable dispersion in the perceptions of the constraints to use this financing source (Table 4 ), as well as the considerable proportion of responses "?" (17\% - 30\%), highlight the lack of information about this financing source, due to lack of experience and knowledge. In particular, 30\% of the SMEs failed to provide a perception (selecting answer "?") regarding the banking regulation quality in the FDI's host country and the local banks reluctance in accepting Portuguese assets as collateral. Respondents agree on banks demand of excessive counter-guarantees (mean: 3.88 \pm 1.11 ) and high interest charges (mean: $3.73 \pm 1.22$ ). Almost $1 / 3$ of the SMEs disagree that lack of reputation and contacts in the local bank market constrain the ability to obtain financing from a local bank. The low amount to be financed or the relative unfamiliarity of the SME management team are also perceived as less relevant factors.

Table 4. Barriers to attracting local bank financing for FDI projects. "To what extent do you agree with the following statements?” (1: totally disagree; 5: totally agree)

\begin{tabular}{|c|c|c|c|c|c|c|c|}
\hline \multirow[t]{2}{*}{ Item } & \multicolumn{5}{|c|}{ Scores $(\%)$} & \multirow{2}{*}{$\begin{array}{l}\text { Mean } \\
(\mathrm{sd})\end{array}$} & \multirow[t]{2}{*}{ Signif. } \\
\hline & 1 & 2 & 3 & 4 & 5 & & \\
\hline “Local banks charge high interests.” & 6.7 & 6.7 & 26.7 & 26.7 & 33.3 & $\begin{array}{c}3.73 \\
(1.22)\end{array}$ & 0.065 \\
\hline “Local banks have high collateral requirements”. & 5.9 & 0.0 & 29.4 & 29.4 & 35.3 & $\begin{array}{c}3.88 \\
(1.11)\end{array}$ & 0.006 \\
\hline "The amount of the loan is too small." & 26.7 & 26.7 & 26.7 & 20.0 & 0.0 & $\begin{array}{c}2.40 \\
(1.12)\end{array}$ & 0.227 \\
\hline $\begin{array}{l}\text { "My SME has a lack of reputation and contacts in the local } \\
\text { bank market." }\end{array}$ & 17.6 & 11.8 & 29.4 & 11.8 & 29.4 & $\begin{array}{c}3.24 \\
(1.48)\end{array}$ & 0.774 \\
\hline “Local banks refuse to accept Portuguese guarantees.” & 21.4 & 21.4 & 35.7 & 7.1 & 14.3 & $\begin{array}{c}2.71 \\
(1.33)\end{array}$ & 0.508 \\
\hline “Local bank regulation is too restrictive.” & 0.0 & 14.3 & 57.1 & 7.1 & 21.4 & $\begin{array}{c}3.36 \\
(1.01)\end{array}$ & 0.688 \\
\hline “My SME is not familiar with local bank regulation." & 5.9 & 41.2 & 47.1 & 5.9 & 0.0 & $\begin{array}{c}2.53 \\
(0.72)\end{array}$ & 0.039 \\
\hline
\end{tabular}

This table provides an overview of barriers relating to attracting local bank financing for FDI projects, reported by the 20 SMEs surveyed. \% score represents the percentage of respondents that have marked each score for the statement. "Mean" is the average score given by the respondents, and "(sd)" is the standard deviation of scores. "Don't know" ("?") answers were excluded. Significance reports the p-value from the twosided sign-test $\left(\mathrm{H}_{0}\right.$ : the difference between median of the variable and $\left.3=0\right)$.

\subsubsection{Domestic bank financing}

For most of the SMEs that do not rely exclusively on internal financing, domestic banks are, by far, the main external source for FDI funding. 8 SMEs (40\%) reported to have resorted to domestic banks to finance FDI (banks operating in Portugal, regardless of the capital nationality). For these firms, domestic banks financed between $20 \%$ and $80 \%$ of the total amount invested.

One of the major constraints to attract domestic bank financing seems to be the domestic assets requirements as collateral (Table 5). This is perceived as more relevant than the limited value of FDI 
assets as collateral. There is also a broad consensus on the restrictions imposed by the requirement of (further) personal collateral (64.7\% of respondents agree; mean: $3.94 \pm 1.25$ ).

Table 5. Barriers to attracting domestic bank financing for FDI projects. "To what extent do you agree with the following statements?" (1: totally disagree; 5 : totally agree)

\begin{tabular}{|c|c|c|c|c|c|c|c|}
\hline \multirow[t]{2}{*}{ Item } & \multicolumn{5}{|c|}{ Scores (\%) } & \multirow{2}{*}{$\begin{array}{l}\text { Mean } \\
\text { (sd) }\end{array}$} & \multirow[t]{2}{*}{ Signif } \\
\hline & 1 & 2 & 3 & 4 & 5 & & \\
\hline "Domestic banks charge high interests." & 11.1 & 22.2 & 38.9 & 16.7 & 11.1 & $\begin{array}{c}2.94 \\
(1.16)\end{array}$ & 1.000 \\
\hline $\begin{array}{l}\text { "The limited financial autonomy of my SME hinders } \\
\text { obtaining FDI bank financing." }\end{array}$ & 5.6 & 27.8 & 38.9 & 11.1 & 16.7 & $\begin{array}{c}3.06 \\
(1.16)\end{array}$ & 1.000 \\
\hline $\begin{array}{l}\text { "FDI assets are very specific and therefore have low } \\
\text { collateral value." }\end{array}$ & 0.0 & 33.3 & 38.9 & 11.1 & 16.7 & $\begin{array}{c}3.11 \\
(1.08)\end{array}$ & 1.000 \\
\hline "Domestic banks requires domestic assets as collateral." & 0.0 & 11.8 & 11.8 & 47.1 & 29.4 & $\begin{array}{c}3.94 \\
(0.97)\end{array}$ & 0.007 \\
\hline $\begin{array}{l}\text { "Domestic banks require (further) personal collateral } \\
\text { for the FDI project." }\end{array}$ & 5.9 & 5.9 & 23.5 & 17.6 & 47.1 & $\begin{array}{c}3.94 \\
(1.25)\end{array}$ & 0.023 \\
\hline $\begin{array}{l}\text { "The limited assets of my SME hinders obtaining FDI } \\
\text { bank financing". }\end{array}$ & 17.6 & 29.4 & 35.3 & 5.9 & 11.8 & $\begin{array}{c}2.65 \\
(1.22)\end{array}$ & 0.227 \\
\hline $\begin{array}{l}\text { "Financial health is more important than company } \\
\text { capitalization". }\end{array}$ & 5.3 & 5.3 & 26.3 & 36.8 & 26.3 & $\begin{array}{c}3.74 \\
(1.10)\end{array}$ & 0.013 \\
\hline $\begin{array}{l}\text { "Domestic bank is hardly interested in FDI, they have a } \\
\text { domestic focus." }\end{array}$ & 5.6 & 5.6 & 22.2 & 22.2 & 44.4 & $\begin{array}{c}3.94 \\
(1.21)\end{array}$ & 0.013 \\
\hline $\begin{array}{l}\text { "Domestic banks are reluctant towards FDI due to } \\
\text { monitoring issues." }\end{array}$ & 5.9 & 0.0 & 29.4 & 35.3 & 29.4 & $\begin{array}{c}3.82 \\
(1.07)\end{array}$ & 0.006 \\
\hline $\begin{array}{l}\text { "Domestic banks do not have the resources and skills } \\
\text { necessary to adequately assess the risk of FDI projects." }\end{array}$ & 6.7 & 26.7 & 26.7 & 26.7 & 13.3 & $\begin{array}{c}3.28 \\
(1.18)\end{array}$ & 0.581 \\
\hline $\begin{array}{l}\text { "Domestic banks only consider lending for acquiring } \\
\text { fixed assets, and not for start-up costs, market studies, } \\
\text { consulting services and business trips required." }\end{array}$ & 0.0 & 17.6 & 23.5 & 23.5 & 35.3 & $\begin{array}{c}3.77 \\
(1.15)\end{array}$ & 0.092 \\
\hline
\end{tabular}

This table provides an overview of statements related to the barriers to attracting domestic bank financing for FDI projects, reported by the 20 SMEs surveyed. \% score represents the percentage of respondents that have marked each score for the statement. "Mean" is the average score given by the respondents, and "(sd)" is the standard deviation of scores. "Don't know" ("?") answers were excluded. Significance reports the p-value from the bilateral two-sided sign-test $\left(\mathrm{H}_{0}\right.$ : the difference between median of the variable and $\left.3=0\right)$.

SMEs agree that firms' financial health is more important than capitalization to get bank lending. In contrast, firms limited financial autonomy and assets are not perceived by most of SMEs as barriers to attract domestic bank financing for their FDI projects.

Concerning banking, the perception that domestic banks have a purely domestic focus $(3.94 \pm 1.21)$ and are mostly willing to finance fixed assets acquisition $(3.77 \pm 1.15)$ is quite common. Domestic banks reluctance towards FDI projects is perceived more as a consequence of the increased difficulties in monitoring this type of investment $(3.82 \pm 1.07)$ than as the result of lacking the adequate resources to evaluate FDI risks (3.28 \pm 1.18$)$. 
SMEs were also questioned about the factors that, according to their perception, banks privilege in the loan decisions about FDI projects. In line with literature, the respondents broadly perceive all the proposed issues as having some importance in banks lending decision (Table 6). The ability to provide collateral, the firm's financial performance and the FDI project risk are the three attributes considered as the most relevant. The SMEs ability to pledge collateral is the most consensually perceived attribute as a key factor (almost 60\% of respondents considered it extremely important). Firm size is the fourth with higher mean score (one-half of the respondents view firm size as "extremely important" in the evaluation of applications for FDI projects funding, suggesting that SMEs perceive that banks do some kind of discrimination among firms, based on size).

Table 6 - Factors domestic banks consider in the evaluation of applications for funding FDI projects.

"How important do you consider the following factors in the evaluation of an IDE project by the domestic bank?" (1: nothing important; 5: extremely important)

\begin{tabular}{|c|c|c|c|c|c|c|c|}
\hline \multirow[t]{2}{*}{ Item } & \multicolumn{5}{|c|}{ Scores $(\%)$} & \multirow[t]{2}{*}{ Mean (sd) } & \multirow[t]{2}{*}{ Signif. } \\
\hline & 1 & 2 & 3 & 4 & 5 & & \\
\hline Country of investment, economic and political stability & 0.0 & 10.0 & 10.0 & 45.0 & 35.0 & $4.05(0.95)$ & 0.001 \\
\hline Presence of strong currency in local country & 0.0 & 10.0 & 0.0 & 60.0 & 30.0 & $4.10(0.85)$ & 0.000 \\
\hline Legal form of the company requesting the financing & 0.0 & 10.5 & 36.8 & 36.8 & 15.8 & $3.58(0.90)$ & 0.039 \\
\hline Tangibility of assets to fund & 0.0 & 5.0 & 15.0 & 65.0 & 15.0 & $3.90(0.72)$ & 0.000 \\
\hline Realism and feasibility of the FDI's business plan & 0.0 & 5.0 & 15.0 & 65.0 & 15.0 & $4.25(0.91)$ & 0.000 \\
\hline Geographic proximity to the Bank's geographic base & 0.0 & 11.1 & 33.3 & 44.4 & 11.1 & $3.56(0.86)$ & 0.039 \\
\hline SME relations and networks & 5.3 & 5.3 & 36.8 & 42.1 & 10.5 & $3.47(0.96)$ & 0.039 \\
\hline Sector of investment & 0.0 & 0.0 & 25.0 & 45.0 & 30.0 & $4.05(0.76)$ & 0.000 \\
\hline Mode of entry into foreign markets & 0.0 & 0.0 & 44.4 & 44.4 & 11.1 & $3.67(0.69)$ & 0.002 \\
\hline Trust and relationship betweel & 0.0 & 5.0 & 25.0 & 35.0 & 35.0 & $4.00(0.92)$ & 0.001 \\
\hline The SME's s & 0.0 & 5.0 & 20.0 & 45.0 & 30.0 & 4.00 & 0.001 \\
\hline The SME's financial performance & 0.0 & 0.0 & 0.0 & 50.0 & 50.0 & $4.50(0.51)$ & 0.000 \\
\hline Management team of the SME & 0.0 & 5.0 & 15.0 & 40.0 & 40.0 & $4.15(0.88)$ & 0.000 \\
\hline Presence of the domestic bank & 0.0 & 5.0 & 30.0 & 35.0 & 30.0 & $3.90(0.91)$ & 0.002 \\
\hline Risk of the FDI project & 0.0 & 0.0 & 10.0 & 40.0 & 50.0 & $4.40(0.68)$ & 0.000 \\
\hline The SME's ability to pledge collateral & 0.0 & 0.0 & 10.0 & 30.0 & 60.0 & $4.50(0.69)$ & 0.000 \\
\hline The SME's experience with FDI & 0.0 & 15.0 & 35.0 & 30.0 & 20.0 & $3.55(1.00)$ & 0.092 \\
\hline Firm size & 0.0 & 0.0 & 12.5 & 37.5 & 50.0 & $4.38(0.74)$ & 0.016 \\
\hline \multicolumn{8}{|c|}{$\begin{array}{l}\text { his table provides an overview of the importance perceived of several factors that banks might consider in evaluating } \\
\text { oan requests for FDI projects, reported by the } 20 \text { SMEs surveyed. \% score represents the percentage of respondents } \\
\text { hat have marked each score for this statement. "Mean" is the average score given by the respondents, and"(sd)" is the } \\
\text { tandard deviation of scores. "Don't know" ("?") answers were excluded. Significance reports the p-value from the two- } \\
\text { ided sign-test ( } \mathrm{H}_{0} \text { : the difference between median of the variable and } 3=0 \text { ). }\end{array}$} \\
\hline
\end{tabular}

Although with a lower degree of relevance, the surveyed SMEs remark that banks consider the sector of investment. Approximately $67 \%$ of the sample agreed with this aspect's relevance (scores 4 and 5). Industry may signal the business risk and, simultaneously, determine the ability to provide collateral. The host country macroeconomic environment is also viewed as relevant to banks lending decisions, once FDI involves increased political and exchange risks, which SMEs perceive as a factor considered in the investment's risk estimation. 


\subsubsection{Financing constraints: summary}

The preference to use internal funds may explain why the surveyed SMEs do not report important constraints in accessing external financing to their FDI projects. 45\% of the surveyed SMEs do not see the search for FDI financing as constraining their growth and/or international expansion (Table 7). A minority of respondents perceive that financing constraints are slowing their international expansion and the mean score for this statement $(2.90 \pm 1.12)$ is very similar to the one regarding firms' growth $(2.85 \pm 1.18)$. For both the sentences, score "2" was the most chosen, indicating disagreement.

Similarly, SMEs report not resorting to more expensive sources due to difficulties in obtaining bank credit for FDI. The internal funds seem to be a low-cost alternative to external financing. The mean score for this sentence (1.78 \pm 1.00 ) is in line with literature (De Maeseneire \& Claeys, 2012), although the percentage of firms that strongly agree with the statement is much lower in Portugal. More than credit availability, interests seem to be a concern. This suggests that Portuguese SMEs do not face constraints in bank credit availability. This is a rather surprising result, since in the financial crisis context, one would expect SMEs to report acute problems in accessing bank finance. Few respondents (33.3\%) perceive that banks deal with the higher risk linked with FDI by credit rationing instead of increasing interest rates. This perception confirms the literature, referring to the problems of adverse selection and moral hazard that would arise from increasing the interest rate. Another remarkable result concerns the SMEs view on the importance of raising equity. Broadly, our respondents do not perceive that raising equity would facilitate bank financing for FDI projects.

Table 7. Financing constraints faced by SMEs pursuing FDI: general overview. "To what extent do you agree with the following statements?" (1: totally disagree; 5 : totally agree)

\begin{tabular}{|c|c|c|c|c|c|c|c|}
\hline \multirow[t]{2}{*}{ Item } & \multicolumn{5}{|c|}{ Scores (\%) } & \multirow[t]{2}{*}{ Mean (sd) } & \multirow[t]{2}{*}{ Signif. } \\
\hline & 1 & 2 & 3 & 4 & 5 & & \\
\hline $\begin{array}{l}\text { "The long lasting search for FDI financing lowers the } \\
\text { growth of my SME." }\end{array}$ & 10.0 & 35.0 & 25.0 & 20.0 & 10.0 & 2.85 (1.18) & 0.607 \\
\hline $\begin{array}{l}\text { "My SME opts for a slower international growth process } \\
\text { due to funding constraints". }\end{array}$ & 5.0 & 40.0 & 25.0 & 20.0 & 10.0 & $2.90(1.12)$ & 0.607 \\
\hline $\begin{array}{l}\text { "My SME uses more expensive funding sources due to } \\
\text { difficulties in bank credit to IDE." }\end{array}$ & 44.4 & 44.4 & 5.6 & 0.0 & 5.6 & $1.78(1.00)$ & 0.000 \\
\hline $\begin{array}{l}\text { My company does not have difficulties in accessing } \\
\text { credit for exporting. }\end{array}$ & 21.1 & 5.3 & 26.3 & 31.6 & 15.8 & 3.16 (1.39) & 0.424 \\
\hline $\begin{array}{l}\text { "Concerning domestic investment, the credit decision } \\
\text { rely more on the collateral than on the potential } \\
\text { profitability of these projects." }\end{array}$ & 10.0 & 15.0 & 30.0 & 30.0 & 15.0 & 3.25 (1.21) & 0.424 \\
\hline $\begin{array}{l}\text { "Concerning FDI, the credit decision rely more on the } \\
\text { collateral than on the potential profitability of these } \\
\text { projects." }\end{array}$ & 5.0 & 10.0 & 25.0 & 45.0 & 15.0 & 3.55 (1.05) & 0.035 \\
\hline $\begin{array}{l}\text { "My SME sometimes does not ask for bank credit for a } \\
\text { valuable though complex FDI project as we know it will } \\
\text { not be granted." }\end{array}$ & 36.8 & 36.8 & 15.8 & 5.3 & 5.3 & 2.05 (1.13) & 0.004 \\
\hline $\begin{array}{l}\text { "Because perceive FDI as more risky, banks ration or } \\
\text { refuse lending rather than rising interest rates." }\end{array}$ & 0.0 & 13.3 & 53.3 & 20.0 & 13.3 & $3.33(0.90)$ & 0.453 \\
\hline $\begin{array}{l}\text { "By raising the SME's equity, FDI bank financing w } \\
\text { be facilitated." }\end{array}$ & 17.6 & 17.6 & 29.4 & 29.4 & 5.9 & $2.88(1.22)$ & 1.000 \\
\hline
\end{tabular}




\begin{tabular}{|c|c|c|c|c|c|c|c|}
\hline $\begin{array}{l}\text { "For my SME, bank credit available is more important } \\
\text { than its cost." }\end{array}$ & 15.0 & 35.0 & 35.0 & 15.0 & 0.0 & $2.50(0.95)$ & 0.092 \\
\hline
\end{tabular}

Respondents perceive that, for FDI, banks decision relies heavily on collateral. For domestic investments, this dependence is less evident. However, the differences in the mean scores are not statistically significant (sign test $\mathrm{p}$ value=0.4531), showing that SMEs perceive no significant differences between investment projects at home or abroad in banks credit dependence on collateral. Considering that firms perceive higher risk associated with FDI and empirical evidence (De Maeseneire and Claeys, 2012), one would expect firms to report greater financial constraints to FDI, as well as negative impacts over their growth and internationalisation process.

Discrimination on FDI projects evaluation based on firms' size does not seem to be a concern (Table 8). In general, the surveyed SMEs do not appear to have a strong conviction on the subject, or do not perceive that large companies benefit from a more favourable treatment from banks concerning the satisfaction of their financing needs, specifically for FDI projects (this is based on the high percentage of responses with "?"). This evidence is somewhat surprising, once we could argue that SMEs could be expected to perceive higher difficulties in getting bank financing for their FDI projects than larger counterparts. Nevertheless, $33.3 \%$ of the respondents believe that large firms may use FDI assets as collateral.

Table 8. Perceived differences concerning banks treatment of firms according to size. "To what extent do you agree with the following statements?" (1: strongly disagree; 5: totally agree)

\begin{tabular}{|c|c|c|c|c|c|c|c|c|}
\hline \multirow[t]{2}{*}{ Item } & \multicolumn{6}{|c|}{ Scores (\%) } & \multirow{2}{*}{$\begin{array}{l}\text { Mean } \\
\text { (sd) }\end{array}$} & \multirow{2}{*}{ Signif. } \\
\hline & 1 & 2 & 3 & 4 & 5 & $?$ & & \\
\hline $\begin{array}{l}\text { In large companies, it is the profitability of the FDI } \\
\text { project that is evaluated by the bank. }\end{array}$ & 20.0 & 20.0 & 60.0 & 0.0 & 0.0 & 35.0 & $\begin{array}{c}2.40 \\
(0.89)\end{array}$ & 1.000 \\
\hline $\begin{array}{l}\text { In large companies, repayment capacity is not } \\
\text { questioned by banks. }\end{array}$ & 28.6 & 14.3 & 28.6 & 28.6 & 0.0 & 25.0 & $\begin{array}{c}2.57 \\
(1.27)\end{array}$ & 0.727 \\
\hline $\begin{array}{l}\text { In addition to interest, banks charge a set of } \\
\text { (fixed) costs that weigh more heavily on SME. }\end{array}$ & 0.0 & 30.0 & 40.0 & 30.0 & 0.0 & 10.0 & $\begin{array}{c}3.00 \\
(0.82) \\
\end{array}$ & 0.388 \\
\hline Large companies can use FDI assets as collateral. & 0.0 & 0.0 & 66.7 & 22.2 & 11.1 & 15.0 & $\begin{array}{c}3.44 \\
(0.73)\end{array}$ & 0.070 \\
\hline
\end{tabular}

This table provides an overview of statements related to perceived differences in banks treatment according to firms' size, reported by the 20 SMEs surveyed. \% score represents the percentage of respondents that have marked each score for this statement. "Mean" is the average score given by the respondents, and"(sd)" indicates the standard deviation of scores. "Don't know" ("?") answers were excluded. Significance reports the p-value from the two-sided sign-test $\left(\mathrm{H}_{0}\right.$ : the difference between median of the variable and $\left.3=0\right)$. 


\section{Discussion and conclusions}

Most of our SMEs reported a strong dependence on internal funds to finance their FDI projects. This dependence could be seen as a symptom of financial constraints (Fazzari, Hubbard, \& Petersen, 1988), but the inquired SMEs do not report to be particularly constrained in their ability to invest (domestically or abroad) due to financing obstacles. Additionally, despite banks being the main source of external financing, respondents do not claim being heavily dependent on banks for neither domestic nor foreign investments. The availability of internal funds may help to explain these findings.

Alongside the provision of a balanced financial situation, the use of own financing by the surveyed SMEs may as well be explained by their reluctance to open up their social capital to new shareholders, as these companies do not admit loss of control in the business' administration as the price to pay for FDI. This issue also arises in connection with the lack of tax incentives, in the private sphere, for entrepreneurs to take this step effectively.

Contradicting the hypothesis of higher financial barriers faced by SMEs in their international expansion projects (Akbar et al., 2014), there is no evidence that Portuguese SMEs perceive that financial constraints remarkably vary between domestic and foreign investments. Collateral requirements are seen by banks as one of the main constraints to FDI financing (either local or domestic). This perception is in line with the hypothesis of foreign assets limited collateral value, since FDI usually entails substantial sunk costs and/or intangible assets (Michaelas, Chittenden, and Poutziouris, 1999; Abor and Biekpe, 2007). The higher the problems in transacting these assets in other markets, the greater the creditors' risk of losses. High requirement of domestic assets as collateral is perceived as more relevant than the limited value of FDI assets as collateral.

Firms access to finance varies across countries, being determined not only by differences in firms' specific characteristics, but also by the constraints posed by countries varying financial development and institutional environment (Ayyagari et al., 2012).

In Portugal, the external financing is somewhat confined to traditional banking, being evident some unfamiliarity with alternative financing sources. Indeed, Portuguese entrepreneurs lack knowledge of alternative financing sources to relieve their dependence on domestic funds to FDI. Thus, we recommend that banks and government could relevantly contribute in this field, as well, we highlight the need for further financial literacy in Portguese SMEs. Comparing our results with those obtained by De Maeseneire and Claeys (2012), we found remarkable differences in the external financing sources used by SMEs to finance FDI. Portuguese firms rely more on domestic banks lending. Venture capital and local (host country) bank lending, specifically, seem to be more widely used by Belgian SMEs. In addition, Portuguese SMEs seem more reluctant to open their capital to new partners and less willing to allow loss of control as the "price to pay" for FDI, comparing to their Belgian counterparts.

Despite using less diversified funding sources, it is noteworthy that Portuguese SMEs report being less constrained in financing their FDI projects than their Belgian counterparts. Likewise, results suggest that Portuguese SMEs also perceive less remarkable differences in funding constraints between domestic and FDI projects. Contradicting theory, in general, the surveyed SMEs do not clearly perceive that SMEs face higher financing constraints than their larger counterparts. De 
Maeseneire and Claeys (2012) found a very different picture in Belgium, where SMEs perceived higher difficulties (related to firms' size) in achieving bank funding for FDI projects.

The qualitative nature of this study and its sampling limitations do not allow generalization of the reported results. On the other hand, it only tells the story of companies that have succeeded in investing abroad. Further analysis should include those firms potentially more affected by these financial restrictions, specifically those that would like to carry out FDI but failed, due to a lack of the necessary financial resources. Despite these limitations, this study contributes to expand the still very limited empirical evidence on SME's FDI financing. Although there is abundant literature on the access to economic agents' financing, to this day this work is the first to focus on the perceptions of Portuguese SMEs about constraints to FDI financing, relying on primary data, hence its originality. Reporting SMEs' reluctance towards external financing, this paper found some signs that there is room for external financers, such as banks, to reconfigure their strategies and products/ services in order to best serve such clients.

\section{Acknowledgements}

The authors thank Wouter De Maeseneire and Tine Claeys, for sharing the questionnaire in which our data collection was based. Two anonymous reviewers provided helpful comments on an earlier draft of the manuscript.

\section{References}

[1] Abor, J., and Biekpe, N. (2007). Small Business Reliance on Bank Financing in Ghana. Emerging Markets Finance and Trade, 43(4), 93-102. DOI: 10.2753/ree1540-496x430405

[2] Akbar, Y., Bortoluzzi, G., and Tracogna, A. (2014). Beyond entry mode-SME escalation in emerging markets: a conceptual framework. Journal for International Business and Entrepreneurship Development, 7(4), 326-340. DOI: 10.1504/JIBED.2014.064452

[3] Arráiz, I., Meléndez, M., and Stucchi, R. (2014). Partial credit guarantees and firm performance: evidence from Colombia. Small Business Economics, 43(3), 711-724. DOI: 10.1007/s11187-014-95584

[4] Artola, C., and Genre, V. (2011). Euro area SMEs under financial constraints: Belief or reality? CESifo Working Paper Series No. 3650. [Online]. Available at: https://www.econstor.eu/bitstream/10419/53136/1/675946697.pdf

[5] Ayyagari, M., Demirguc-Kunt, A., and Maksimovic, V. (2012). Financing of firms in developing countries: lessons from research. The World Bank. [Online]. Available at: https://openknowledge.worldbank.org/bitstream/handle/10986/6038/WPS6036.pdf. DOI: 10.1596/1813-9450-6036

[6] Bãdulescu, D. (2010). SMEs Financing: the Extent of Need and the Responses of Different Credit Structures. Theoretical and Applied Economics, 17(7), 25-36.

[7] Bakare, A., and Akinbode, J. (2016). Development Financial Institutions and Small Medium Enterprises Development in Osun State, Nigeria. OSOGBO Journal of Management, 1(2), 6-17.

[8] Barbosa, E., and Moraes, C. (2004). Determinants of the firm's capital structure: The case of the very small enterprises. Economics Working Paper Archive at WUSTL, Finance, 302001. [Online]. Available at: https://econwpa.ub.uni-muenchen.de/econ-wp/fin/papers/0302/0302001.pdf 
[9] Barradas, R., Lagoa, S., Leão, E., and Mamede, R. (2013). FESSUD Studies in Financial Systems No 9 Report on the financial system in Portugal. Financialisation, Economy, Society and Sustainable Development (FESSUD) Project, Lisbon. [Online]. Available at: https://www.researchgate.net/publication/318883412_Report_on_the_Financial_System_in_Portuga l/download

[10] Beck, T., Degryse, H., De Haas, R., and Van Horen, N. (2018). When arm's length is too far: Relationship banking over the credit cycle. Journal of Financial Economics, 127(1), 174-196. DOI: 10.1016/j.jfineco.2017.11.007

[11] Beck, T., Demirgüç-Kunt, A., and Maksimovic, V. (2005). Financial and legal constraints to growth: does firm size matter? The Journal of Finance, 60(1), 137-177. DOI: 10.1111/j.1540-6261.2005.00727

[12] Beck, T., Demirguc-Kunt, A., and Martinez Peria, M. (2008). Bank financing for SMEs around the world: Drivers, obstacles, business models, and lending practices. The World Bank. [Online]. Available at: https://openknowledge.worldbank.org/bitstream/handle/10986/6315/WPS4785.pdf. DOI: 10.1596/1813-9450-4785

[13] Beck, T., Demirgüç-Kunt, A., Laeven, L., and Maksimovic, V. (2006). The determinants of financing obstacles. Journal of International Money and Finance, 25(6), 932-952. DOI: 10.1016/j.jimonfin.2006.07.005

[14] Berger, A., and Udell, G. (2002). Small business credit availability and relationship lending: The importance of bank organisational structure. The Economic Journal, 112(477), F32-F53. DOI: $10.2139 /$ ssrn.285937

[15] Berger, A., Espinosa-Vega, M., Frame, W., and Miller, N. (2011). Why do borrowers pledge collateral? New empirical evidence on the role of asymmetric information. Journal of Financial Intermediation, 20(1), 55-70. DOI: 10.1016/j.jfi.2010.01.001

[16] Boot, A., Thakor, A., and Udell, G. (1991). Secured lending and default risk: Equilibrium analysis, policy implications and empirical results. Economic Journal, 101(406), 458-472. DOI: 10.2307/2233552

[17] Buch, C., Kesternich, I., Lipponer, A., and Schnitzer, M. (2009). Financial Constraints and the Margins of FDI. CEPR Discussion Paper 7444. [Online]. Available at: https://www.econstor.eu/bitstream/10419/28391/1/610385089.PDF. DOI: 10.5282/ubm/epub.11054

[18] Buch, C., Kesternich, I., Lipponer, A., and Schnitzer, M. (2014). Financial constraints and foreign direct investment: firm-level evidence. Review of World Economics, 150(2), 393-420. DOI: 10.1007/s10290013-0184-z

[19] Cerqueiro, G., Ongena, S., and Roszbach, K. (2016). Collateralization, bank loan rates, and monitoring. The Journal of Finance, 71(3), 1295-1322. DOI: 10.1111/jofi.12214

[20] Coluzzi, C., Ferrando, A., and Martinez-Carrascal, C. (2015). Financing obstacles and growth: an analysis for euro area non-financial firms. The European Journal of Finance, 21(10-11), 773-790. DOI: $10.1080 / 1351847 X .2012 .664154$

[21] Ćorić, B. (2010). Investments and capital market imperfections, identification issues: a survey. Financial theory and practice, 34(4), 407-434.

[22] Cressy, R., and Olofsson, C. (1997). European SME financing: an overview. Small Business Economics, 9(2), 87-96. DOI: 10.1023/A:1007921004599

[23] Daskalakis, N., Jarvis, R., and Schizas, E. (2013). Financing practices and preferences for micro and small firms. Journal of Small Business and Enterprise Development, 20(1), 80-101. DOI: $10.1108 / 14626001311298420$

[24] De Maeseneire, W., and Claeys, T. (2012). SMEs, FDI and financial Constraints: The case of Belgium. International Business Review, 21(3), 408-424. D0I: 10.1016/j.ibusrev.2011.03.004 
[25] Degryse, H., and Van Cayseele, P. (2000). Relationship lending within a bank-based system: Evidence from European small business data. Journal of financial Intermediation, 9(1), 90-109. DOI: 10.1006/jfin.1999.0278

[26] ECB. (June 2018). Survey on the Access to Finance of Enterprises in the euro area. Frankfurt am Main, Germany: European Central Bank. [Online]. Available at: https://www.ecb.europa.eu/stats/accesstofinancesofenterprises/pdf/ecb.accesstofinancesmallmedi umsizedenterprises201806.en.pdf?f39a5afa92e40c051dfb5dde764306ba

[27] European Commission. (2003). Observatory of European SMEs. SMEs and Access to Finance. Luxembourg: Office for Official Publications of the European Communities. [Online]. Available at: https://ec.europa.eu/docsroom/documents/3232/attachments/1/translations/en/renditions/nativ e

[28] Fazzari, S., Hubbard, R., and Petersen, B. (1988). Financing constraints and corporate investment. Brookings Papers on Economic Activity, 1, 141-195. DOI: 10.2307/2534426

[29] Ferrando, A., and Griesshaber, N. (2011). Financing obstacles among euro area firms: Who suffers the most? Frankfurt: European Central Bank. [Online]. Available at: https://www.econstor.eu/bitstream/10419/153727/1/ecbwp1293.pdf

[30] Franco, M., and Haase, H. (2010). Failure factors in small and medium-sized enterprises: qualitative study from an attributional perspective. International Entrepreneurship and Management Journal, 6(4), 503-521. DOI: $10.1007 / \mathrm{s} 11365-009-0124-5$

[31] Giudici, G., and Paleari, S. (2000). The provision of finance to innovation: a survey conducted among Italian technology-based small firms. Small Business Economics, 14(1), 37-53. DOI: 10.1023/A:1008187416389

[32] Haniff, A., Akma, L., and Lee, S. (2017). Access to Financing for SMEs: Perception and Reality. Central Bank of Malaysia, Development Finance and Enterprise Department. [Online]. Available at: http://www.bnm.gov.my/index.php?ch=en_publicationandpg=en_staffinsightandac=51andbb=file

[33] Harris, M., and Raviv, A. (1991). The theory of capital structure. The Journal of Finance, 46(1), 297 355. DOI: $10.1111 / \mathrm{j} .1540-6261.1991 . t b 03753 . x$

[34] Hossain, M., Ibrahim, Y., and Uddin, M. (2016). Towards the factors affecting small firm growth: Review of previous studies. International Journal of Academic Research in Business and Social Sciences, 6(5), 217-235. DOI: 10.6007/IJARBSS/v6-i5/2127

[35] Howorth, C. A. (2001). Small firms' demand for finance: A research note. International Small Business Journal, 19(4), 78-86. DOI: 10.1177/0266242601194005

[36] Hubbard, R. G. (1988). Capital-Market Imperfections and Investment. Journal of Economic Literature, 36(1), 193-225. DOI: 10.2307/2564955

[37] Huett, P., Baum, M., Schwens, C., and Kabst. (2014). Foreign direct investment location choice of smalland medium-sized enterprises: The risk of value erosion of firm-specific resources. International Business Review, 23(5), 952-965. DOI: 10.1016/j.ibusrev.2014.02.007

[38] Informa DandB. (2016). Longevidade Empresarial em Portugal (2nd ed.). http://biblioteca.informadb.pt/files/files/Estudos/SE-longevidade-empresarial-em-Portugal.pdf. Accessed in May 2017.

[39] Klonowski, D. (2012). Liquidity gaps in financing the SME sector in an emerging market: evidence from Poland. International Journal of Emerging Markets, $7(3)$, 335-355. DOI: $10.1108 / 17468801211237072$

[40] Knight, G., and Liesch, P. (2016). Internationalization: From incremental to born global. Journal of World Business, 51(1), 93-102. DOI: 10.1016/j.jwb.2015.08.011 
[41] Kuntchev, V., Ramalho, R., Rodríguez-Meza, J., and Yang, J. (2013). What have we learned from the Enterprise Surveys regarding access to finance by SMEs? The World Bank. DOI: 10.1596/1813-94506670

[42] Lu, J., and Beamish, P. (2001). The internationalization and performance of SMEs. Strategic Management Journal, 22(6-7), 565-586. DOI: 10.1002/smj.184

[43] Mason, C., and Kwok, J. (2010). Investment readiness programmes and access to finance: a critical review of design issues. Local Economy, 25(4), 269-292. DOI: 10.1080/02690942.2010.504570

[44] Michaelas, N., Chittenden, F., and Poutziouris, P. (1999). Financial policy and capital structure choice in U.K. SMEs: Empirical evidence from company panel data. Small Business Economics, 12(2), 113-130. DOI: $10.1023 / \mathrm{A}: 1008010724051$

[45] Minetti, R., and Zhu, S. (2011). Credit constraints and firm export: Microeconomic evidence from Italy. Journal of International Economics, 83(2), 109-125. DOI: 10.1016/j.jinteco.2010.12.004

[46] Modigliani, F., and Miller, M. (1958). The cost of capital, corporation finance and the theory of investment. The American Economic Review, 48(3), 261-297.

[47] Mulier, K., Schoors, K., and Merlevede, B. (2016). Investment-cash flow sensitivity and financial constraints: Evidence from unquoted European SMEs. Journal of Banking and Finance, 73, 182-197. DOI: 10.1016/j.jbankfin.2016.09.002

[48] Myers, S. C. (1984). The capital structure puzzle. The Journal of Finance, 39(3), 574-592. DOI: 10.1111/j.1540-6261.1984.tb03646.x

[49] North, D., Baldock, R., and Ekanem, I. (2010). Is there a debt finance gap relating to Scottish SMEs? A demand-side perspective. Venture Capital, 12(3), 173-192. DOI: 10.1080/13691061003658670

[50] Oakey, R. (2007). A commentary on gaps in funding for moderate 'non-stellar'growth small businesses in the United Kingdom. Venture Capital, 9(3), 223-235. DOI: 10.1080/13691060701410160

[51] Rajan, R., and Zingales, L. (1995). What Do We Know about Capital Structure? Some Evidence from International Data. The Journal of Finance, 50(5), 1421-1460. DOI: 10.1111/j.15406261.1995.tb05184.x

[52] Scherr, F., Sugrue, T., and Ward, J. (1993). Financing the small firm start-up: Determinants of debt use. The Journal of Entrepreneurial Finance, 3(1), 17-36.

[53] Simões, V., Castro, A., and Rodrigues, V. (2001). A internacionalização das empresas portuguesas: uma perspectiva genérica. Lisboa: GEPE - Gabinete de Estudos e Prospectiva Económica, Ministério da Economia.

[54] Stiglitz, J., and Weiss, A. (1981). Credit rationing in markets with imperfect information. The American economic review, 71(3), 393-410. DOI: 10.2139/ssrn.1010965

[55] Trigo, V., Calapez, T., and Santos, M. (2009). Internacionalização e PME: um estudo empírico sobre PME em Portugal. Economia Global e Gestão, 14(3), 9-24. Available at: $<$ http://www.scielo.mec.pt/scielo.php?script=sci_arttext\&pid=S0873$74442009000300002 \& \operatorname{lng}=p t \& n r m=i s o>$. ISSN 0873-7444.

[56] Walker, D. A. (1989). Financing the small firm. Small Business Economics, 1(4), 285-296.

[57] Wang, X. (2016). Financial Constraints and Exports. [Online]. Available at SSRN: https://ssrn.com/abstract=2698358. DOI: $10.2139 /$ ssrn.269835

[58] Wang, Y. (2016). What are the biggest obstacles to growth of SMEs in developing countries?-An empirical evidence from an enterprise survey. Borsa Istanbul Review, 16(3), 167-176. DOI: 10.1016/j.bir.2016.06.001 